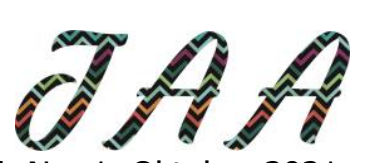

Vol. 6, No. 1, Oktober 2021

\title{
PENGARUH KEJELASAN SASARAN ANGGARAN, PENGENDALIAN AKUNTANSI, SISTEM PELAPORAN DAN PEMANFAATAN TEKNOLOGI INFORMASI TERHADAP AKUNTABILITAS KINERJA INSTANSI PEMERINTAH DAERAH (AKIP)
}

\author{
Deni Harianto \\ Fakultas Ekonomi dan Bisnis, Universitas Riau \\ deni.harianto2422@student.unri.ac.id \\ Kennedy \\ Fakultas Ekonomi dan Bisnis, Universitas Riau \\ kennedy@lecturer.unri.ac.id \\ Arumega Zarefar \\ Fakultas Ekonomi dan Bisnis, Universitas Riau \\ arumega@lecturer.unri.ac.id
}

Article History:

Received: 22 Agustus 2021

Revised: 20 September 2021

Accepted: 20 September 2021

DOI: $10.29303 /$ jaa.v6i1.111
Abstract: This research purposes to determine: (1) the impact of explication on budget goals on the show accountability of local government agencies, (2) the effect of accounting control on the display of local government agencies, (3) the effect of the reporting system on the accountability of the performance of local government agencies, (4) the effect of the use of information technology on the performance responsibility of local government agencies. There were 26 Regional Apparatus Organizations in this research as a population of Rokan Hilir Regency. The samples utilized were 51 respondents using the proportional stratified random sampling technique. The research implemented data by distributing questionnaires. The analytical technique impelemented is multiple linier regression analysis. The analytical device employed in this study was the Statistical Product and Service Solution (SPSS) 23.0 version. This study indicated that: (1) the clearance of the budget goals had an influence on the show accountability of internal regime $.000<0.05$, (2) accounting control affects the performance accountability of local government agencies with a significant level of $0.000<0.05$, (3) the reporting system has an effect on the performance accountability of local government agencies with a significant level of 0.000 $<0.05$, (4) the use of information technology has an effect on the performance accountability of local 
government agencies with a significant level of 0.000 $<0.05$.

Abstrak: Studi yang dikaji mempunyai tujuan dalam menguji: (1) dampak kejelasan anggaran terhadap akuntabilitas kinerja pemerintah daerah, (2) dampak pengendalian akuntansi terhadap akuntabilitas kinerja lembaga pemerintah daerah, (3) pengaruh mekainsme laporan terhadap responsibilitas kompetensi pemerintah daerah, (4) pengaruh pemanfaatan teknologi informasi terhadap responsibilitas kinerja lemaga pemerintah daerah. Populasi dalam studi yang dilakukan ialah sebanyak 26 Organisasi Perangkat Daerah Kabupaten Rokan Hilir. Pada studi yang dilakukan, terdapat 51 informan sebagai sampel dengan memakai teknik proportional strafied random sampling. Riset ini memakai data primer dengan cara mendistribusikan kuesioner/angket. Metode analisa yang diterapkan ialah analisis regrewsi linier berganda. Sedangkan perangkat analisa yang diterapkan ialah Statistical Product and Servise Solution (SPSS) versi 23.0. Hasil studi yang dilakukan mengindikasikan bahwasanya: (1)kejelasan sasaran anggaran berpengaruh terhadap akuntabilitas kinerja instansi pemerintah daerah dengan tingkat signifikan 0,000 < 0,05, (2) pengendalian akuntansi berpengaruh terhadap akuntabilitas kinerja instansi pemerintah daerah dengan tingkat signifikan sebesar $0,000<0,05$, (3) sistem pelaporan berpengaruh terhadap akuntabilitas kinerja instansi pemerintah daerah dengan tingkat signifikan 0,000 < 0,05, (4) pemanfatan teknologi informasi berpengaruh terhadap akuntabilitas kinerja instansi pemerintah daerah dengan tingkat signifikan $0,000<0,05$

Keywords: Clarity of Budget Objectives, Accounting Control, Information Technology Utilization Reporting System, Performance Accountability of Local Government Agencies.

Kata kunci: Kejelasan Sasaran Anggaran, Pengendalian Akuntansi, Sistem Pelaporan, Pemanfaatan Teknologi Informasi, Akuntabilitas Kinerja Instansi Pemerintah Daerah. 


\section{$D A A$}

Vol. 6, No. 1, Oktober 2021

\section{PENDAHULUAN}

Kinerja instansi pemerintah ialah ilustrasi tentang tingkat pemenuhan target maupun lembaga pemerintah selaku penguraian misi, visi serta rancangan lembaga kepemerintahan yang memperlihatkan level kesuksesan serta ketidakberhasilan penerapan aktivitas-aktivitas berdasarkan program serta peraturan yang diputuskan yang membuat terbentuknya pelayanan kepada masyarakat. Melalui penilaian kinerja, pemerintah akan bisa memutuskan beragam cara dalam menjaga ataupun memaksimalkan kinerjanya. Penilaian kinerja dilaksanakan dengan membandingkan antara kinerja yang semestinya dilaksanakan dengan yang diinginkan dimana didalam laporan kinerja harus mencerminkan kedudukan kinerja lembaga pemerintah.

Tahun 2017 BPK Perwakilan Provinsi Riau melaksanakan peninjauan untuk LKPD pada Pemerintah Kabupaten Rokan Hilir. Dari LKPD Kabupaten Rokan Hilir, BPK RI menyampaikan pendapat Wajar Dengan Pengecualian (WDP) untuk LKPD Kabupaten Rokan Hilir Tahun 2017. Pendapat tersebut sejalan dengan yang disampaikan BPK RI untuk LKPD Tahun 2016. Sejak berdirinya kabupaten Rokan Hilir (Rohil) belum pernah sama sekalipun dapat wajar tanpa pengecualian (WTP). Kemudian berdasarkan laporan hasil evaluasi KemenPAN-RB tentang Laporan Kinerja Lembaga Pemerintah bahwa, tingkat Akuntabilitas Kapasitas Lembaga Pemerintah Kabupaten Rokan Hilir pada 2016 masih mendapat nilai C. Kepala Perencanan Pembangunan Daerah (Bappeda) Kabupaten Rokan Hilir berharap seluruh Organisasi Perangkat Daerah (OPD) harus serius dan komitmen dalam meningkatkan kinerja mereka, hal ini disampaikan setelah melihatnya rendahnya tingkat akuntabilitas kinerja OPD Pemerintahan Kabupaten Rokan Hilir.

Penelitian ini mengkaji salah satu faktor di mana berpotensi bisa memberikan pengaruh untuk kinerja instansi pemerintah diantaranya yakni: pengendalian akuntansi, sistem pelaporan, kejelasan sasaran anggaran, dan pemanfaatan teknologi informasi.

Pertama, perihal kejelasan sasaran anggaran. "Kejelasan sasaran anggaran merupakan sejauh mana tujuan anggaran ditetapkan secara jelas dan spesifik dengan tujuan agar anggaran tersebut dapat dimengerti oleh orang yang bertanggung jawab atas pencapaian sasaran anggaran tersebut." Eksistensi tujuan dana yang tidak samar dan keringanan yang diperoleh personalia didalam merancang sasaran-sasaran finansial, pastinya akan apa yang sudah diagendakan sesuai target (Darwanis dan Chairunnisa, 2013).

Faktor kedua yaitu pengendalian akuntansi . akuntansi keuangan daerah ialah "proses pemahaman, penilaian, penulisan, serta pelaporan keuangan dari entitas pemerintah daerah yang dibuat selaku informasi didalam penetapan keputusan ekonomi yang dibutuhkan oleh pihak-pihak eksternal entitas pemda". 
Faktor yang ketiga yaitu sistem pelaporan. Unsur ini merupakan "laporan yang mencerminkan sistem pertanggungjawaban dari bawahan kepada atasan. sistem pelaporan yang bagus dibutuhkan supaya bisa mengawasi serta mengontrol kinerja manejerial didalam menjalankan anggaran yang sudah diputuskan".

Faktor yang ke empat yaitu pemanfaatan teknlogi informasi. Pemanfaatan informasi teknologi yaitu kebiasan seorang akuntan ketika memakai informasi teknologi dalam menuntaskan tanggung jawab serta memaksimalkan kinerjanya.

\section{KAJIAN TEORI}

\section{Teory Keagenan ( Agency)}

Akuntabilitas pada mulanya ditandai dengan kemunculan diferensiasi antara manajemen dan pemilik. Manajamen dilabeli "agent" sedangkan pemilik dicap "parcipal". Keterkaitan dianggap bertalian dengan korelasi keaganenan (agency intercourse) menurut banyak pakar responsibilitas unjuk kerja lembaga pemerintahan ialah suatu pemahaman di mana dilandaskan kepada perspektif keaagenan. Pemerintah dalam hal ini berperan menjadi perantara (agen) memiliki wewenang dalam menyediakan data transparan serta akurat kepada khalayak sebagai prinsipal sehingga dengan demikian mereka dapat paham dan melakukan evaluasi jenjang berhasil atau ketidakberhasilan dalam menjalankan tanggungjawab dan amanah yang diemban. (prencelina,2019).

\section{Akuntabilitas Kinerja Instansi Pemerintah (AKIP)}

AKIP di mana adalah kependekan dari Akuntabilitas Kinerja Instansi Pemerintah ialah "suatu perwujudan kewajiban suatu instansi pemerintah agar mempertanggung jawabkan keberhasilan/kegagalan pelaksanaan visi, misi dan tujuan organisasi dalam mencapai tujuan-tujuan dan sasaransasaran yang telah ditetapkan melalui alat pertanggungjawaban secara periodic" (PP No.29 Tahun 2014). Perwujudan tanggungjawab ini kemudian dipublikasikan dengan format laporan yang disebut Akuntabilitas Kinerja Instansi Pemerintah (LAKIP).

Pada peraturan Presiden Republik Indonesia Nomor 29 Tahun 2014 menjelaskan bahwa Sistem Akuntabilitas Kineraja Instansi Pemerintah dapat di ketahui indikatornya yaitu: 1) Perencanan Kinerja. 2) Pengukuran Kompetensi 3) Capaian Kinerja. 4) Pelaporan Kinerja 5) Penilaian domestik. 6) Pemanfaatan Informasi Kapabilitas.

\section{Kejelasan Sasaran Anggaran}

Sulichin dan Suharono (2006) berpandangan "Kejelasan sasaran anggaran merupakan sejauh mana tujuan anggaran ditetapkan secara jelas dan spesifik dengan tujuan agar anggaran tersebut dapat dimengerti oleh 


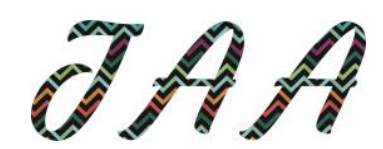

Vol. 6, No. 1, Oktober 2021

orang yang bertanggung jawab atas pencapaian sasaran anggaran tersebut."

Variabel ketidaksamaran sasaran anggaran dihitung dalam upaya memakai instrument sebagaimana yang diuraikan oleh Abdul,Halim (2002). Pernyataan Pernyataan tersebut dihitung dengan memakai lima indikator variabel ialah : 1) ranah program, 2) material, 3)rancangan, 4) jenjang deportasi, 5) sentral tanggungjawab (Netty, 2011).

\section{Pengontrolan Akuntansi}

Pendapat lain, Halim (2007: 42) menerangkan, akuntansi keuangan daerah ialah proses pemahaman, penilaian, penulisan, serta pelaporan keuangan dari entitas pemerintah daerah yang dibuat selaku penunjuk didalam penetapan perekonomian yang dibutuhkan pihak eskternal gatra Pemda.

Variabel Pengendalian Akuntansi dihitung dengan memakai instrumen yang dikembangkan Herawaty (2011) dalam Wahyuni (2014). Pernyataan tersebut ditinjau dengan tiga tolak ukur variabel, yakni:

1) Kesempurnaan pelaporan keuangan,

2) Kepatuhan kepada peraturan undang-undang yang ditetapkan dan hukum, dan

3) Efesiensi serta efektivitas manuver

\section{Sistem Pelaporan}

Ialah "laporan yang mencerminkan sistem pertanggungjawaban dari bawahan kepada atasan. sistem pelaporan yang bagus dibutuhkan supaya bisa mengawasi serta mengontrol kinerja manejerial didalam menjalankan anggaran yang sudah diputuskan" (Abdullah,2005).

Variabel Sistem Pelaporan dihitung dengan memakai instrument yang diuraikan oleh Herawaty (2011) dalam Reyhan (2017). Pernyataan ini diukur dengan memakai tiga indikator variabel, ialah:

1. Pemicu timbulnya penyimpangan,

2. Sikap yang ditentukan, serta

3. Lamanya waktu perbaikan

\section{Pemanfaatan Teknologi Informasi}

Pendayagunaan modernisasi dalam hal ini ialah teknologi informasi "sesuatu yang diinginkan oleh pemakai sistem informasi didalam menjalankan tugasnya". Penilaiannya sesuai intensitas pemanfaatannya, frekuensi pemanfaatan serta total aplikasi yang dipakai. Pemanfaatan teknologi informasi yang akurat serta dibantu oleh kemahiran personil yang menjalakannya bisa memaksimalkan kinerja perusahaan serta individu yang berkaitan. 
Indikator yang digunakan dalam pemanfaatan teknologi informasi menurut (Zodia, 2015) antara lain yaitu :

1. Dimensi sasaran yang mendapat bantuan dari proyek bagian IT.

2. Kesempatan usaha yang IT tawarkan.

3. Data akurat perihal pendayagunaan IT dan deskripsi lingkup serta mutu IT yang diaplikasikan.

4. Penyusunan kerja yang diutamakan pada IT.

\section{Kerangka Pemikiran dan Hipotesis}

Ketidak jelasan sasaran anggaran membuat keliru, tidak diam serta puas didalam bekerja, keterkaitannya pada penyusutan kinerja atau akuntablitas kinerja pemerintah (shuartono dan Mochammad, 2006). Terdapatnya tujuan anggaran yang nyata, berarti agar mempermudahkan dalam mengamanahkan kesuksesan/kegagalan penerapan tugas organisasinya memenuhi tujuan serta sasaran yang sudah diputuskan terdahulu.

Pendapat ini didukung oleh riset yang diinvestigasi oleh Imam wahid (2016) mengungkapkan bahwa kejelasan sasaran anggaran berdampak positif pada akuntabilitas kinerja instansi pemerintah.

H1 : (Kejelasan Sasaran Anggaran Berpengaruh Terhadap Akuntabilitas Kinerja Instansi Pemerintah)

\section{Pengaruh Pengendalian Akuntansi Terhadap Akuntabilitas Kinerja Instansi Pemerintah}

William K. Carter (2009:14) mengklaim, kegunaan pengendalian akuntansi ialah bertanggungjawab untuk pengendalian biaya. Pengendalian biaya semestinya diamanahkan untuk seseorang tertentu yang bertugas untuk memperkirakan biaya. Pada pengendalian biaya terdapat istilah standard. Hal ini juga di dukung oleh Siti Ruri Suhaesta (2016) yg mengatakan Pengendalian Akuntansi berpengaruh signifikan berdampak akuntabilitas kinerja instansi pemerintah.

H2: (Pengendalian Akuntansi Berpengaruh Terhadap Akuntabilitas Kinerja Instansi Pemerintah)

\section{Pengaruh Sistem Pelaporan Terhadap Akuntabilitas Kinerja Instansi Pemerintah}

BPKP (2011) menyebutkan, sebagian ciri laporan yang bagus misal relevan, tepat waktu, bisa diharapkan, mudah mengerti, tegas serta konsisten, tidak kontradiktif antar unit, berdaya banding tinggi, berdaya uji, lengkap, netral, padat serta terstandarisasi.

Berdasarkan riset yang dilakukan oleh Reyhan Handy Fauzan (2017) mengatakan bahwa ada jalinan yang positif atas sistem pelaporan dengan akuntabilitas instansi pemerintah. Siti Ruri Suhaesta (2016) juga mengungkapkan bahwa sistem pelaporan berdampak pada akuntabilitas 


\section{$D A$}

Vol. 6, No. 1, Oktober 2021

kinerja instansi pemerintah. Sedangkan menurut Eko Setiawan (2013) tidak ada pengaruh antara sistem pelaporan pada akuntabilitas kinerja instansi pemerintah.

H3: (Sistem Pelaporan Berpengaruh Terhadap Akuntabilitas Kinerja Instansi Pemerintah)

\section{Pengaruh Pemanfaatan Teknologi Informasi Terhadap Akuntabilitas Kinerja Instansi Pemerintah}

Pemanfaatan teknologi informasi dinilai dari dependensi pengguna pada system informasi yang tersedia dalam menjalankan tugas serta memaksimalkan kinerja.

Sementara Razi (2017) menyebutkan suatu teknologi informasi lebih berperan untuk pengembangan pelayanan bagian public. Chintya (2015) juga mengklaim karena pemanfaatan teknologi informasi berdampak pada kinerja instansi pemerintah pada penilitian yang dilaksanakan di kota solok.

H4: (Pemanfaatan Teknologi Informasi Berpengaruh terhadap Akuntabilitas Kinerja Instansi Peemerintah)

\section{Model Penelitian}

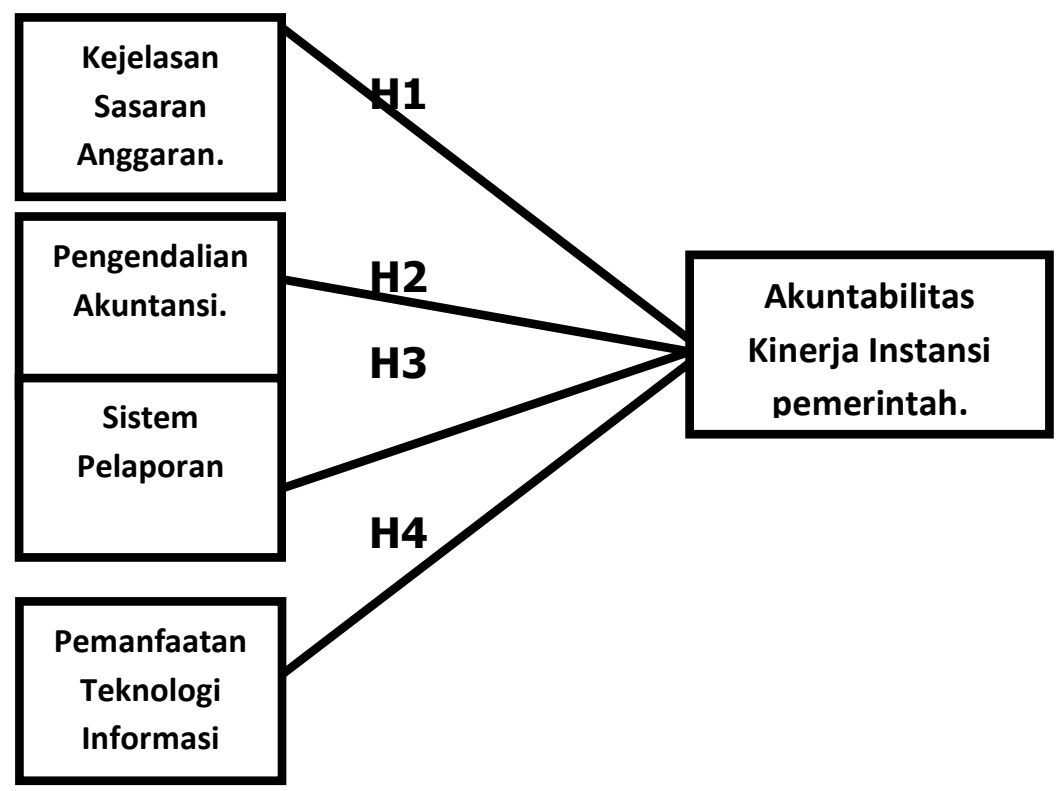

\section{Populasi dan Sampel}

\section{METODE PENELITIAN}

Adapun populasi untuk studi yang dikaji ini ialah semua Organisasi Perangkat Daerah (OPD) yang terdapat Kabupaten Rokan Hilir total 26 OPD. Seluruh populasi dibuat sampel pada riset yang dilakukan. Adapun responden untuk studi yang dikaji ialah Kepala Dinas/Badan, Kasubag 
Perencanaan Evaluasi \& Pelaporan dan Kasubag Keuangan dari tiap-tiap OPD. Waktu penelitian ini dimulai tahun 2020 sampai dengan selesai. Alasan menjadikan Kabupaten Rokan Hilir sebagai tempat penelitian karena fenomena peneliti terjadi di Kabupaten Rokan Hilir, dan masih ada permasalahan mengenai akuntabilitas kinerja instansi pemerintah.

\section{Jenis dan Sumber Data}

Tipe informasi atau data pada studi yang dikaji yaitu menggunkan data primer, yakni perolehan data yang didapat pertama kali dari indvidu atau perorangan oleh peneliti (Umar, 2011:42). Pada riset yang dikaji memakai data di mana didapatkan berdasarkan daftar pertanyaan dalam bentuk kuesioner kepada seluruh OPD Kabupaten Rokan Hilir yang menjadi responden untuk penelitian ini. Sumber data dalam penelitian ini diperoleh dari Instansi Pemerintah Daerah Kabupaten Rokan Hilir.

\section{Metode Penghimpunan Data}

Metode penghimpunan informasi untuk studi yakni memakai cara mendistribusikan lembaran kuesioner secara langsung kapada informan yg sudah di tentukan sebelumnya agar dapat meninjau pada responden tersebut.

\section{Analisis Statistik Deskriptif}

Analisis data dilakukan dalam metode deskriptif yang merpakan suatu metode yang dimana menganalisis data dengan cara data dikumpulkan, disusun, diinterprestasikan,serta di analisis agar guna untuk memberikan keterangan bagi pemecahan masalah yangdihadapi.

\section{Teknik Analisis Data}

Semua pengujian yang dilakukan dilandaskan kepada persamaan regresi liniar berganda di bawah ini:

\begin{tabular}{|c|c|}
\hline & $\begin{array}{l}+\mathbf{b}_{1} \mathbf{X}_{\mathbf{1}}+\mathbf{b}_{2} \mathbf{X}_{2}+\mathbf{b}_{3} \mathbf{X}_{3}+\mathbf{b}_{4} \mathbf{X}_{4}+\mathbf{e} \\
\text { asan: }\end{array}$ \\
\hline Y & : Akuntabilitas Kinerja Instansi Pemerintah \\
\hline$X_{1}$ & : Kepastian tujuan anggaran \\
\hline$X_{2}$ & : Pengendalian Akuntansi \\
\hline$x_{3}$ & : Mekanisme Pelaporan \\
\hline$X_{4}$ & : Pemanfaatan Teknologi Informasi \\
\hline a & : Konstanta \\
\hline$b_{1}$ & : Koefisien regresi dari $X_{1}$ \\
\hline$b_{2}$ & : Koefisien regresi dari $X_{2}$ \\
\hline$b_{3}$ & : Koefisien regresi dari $X_{3}$ \\
\hline$b_{4}$ & : Koefisien regresi dari $X_{4}$ \\
\hline e & : Kesalahan residual (error turn) \\
\hline
\end{tabular}




\section{$D A$}

Vol. 6, No. 1, Oktober 2021

\section{Gambaran Objek Penelitian}

\section{HASIL DAN PEMBAHASAN}

Adapun yang menjadi objek penelitan dalam penelitian ini yaitu Organisasi Perangkat Daerah (OPD) yang ada di kabupaten Rokan Hilir yang berjumlah sebanyak 26 OPD. Kuesioner disebarkan sebanyak 78, pada saat pengambilan 51 kuesioner yang kembali dan seluruhnya dapat diolah. Sedangkan metode pengambilan sampel yang digunakan dalam penelitian ini adalah purposive sampling, yaitu teknik penentuan sampel dengan pertimbangan tertentu. Kriteria anggota populasi yang menjadi sampel yaitu Kepala Dinas/Badan, Kasubag Perencanaan Evaluasi dan Pelaporan dan Kasubag Keuangan dari tiap-tiap OPD.

Dalam penyebaran kuesioner, tidak semua responden bersedia langsung untuk mengisi kuesioner yang di bagikan dan disebarkan karena kesibukan dari responden. Responden meminta agar kuesioner di tinggalkan, sehingga peneliti tidak bisa mengendalikan jawaban responden. Oleh karena itu, jawaban yang diberikan oleh responden belum tentu menggambarkan keadaan sebenarnya. Untuk melihat tingkat pengembalian dan kelayakan pengelola kuesioner dapat dilihat sebagai berikut :

Diketahui bahwa dari 78 kuesinoer (100\%) yang disebarkan, dari 78 sebaran kuesioner yang disebarluaskan, tanggapan yang masuk kepada peneliti ialah sebanyak 51 kuesioner. Sehingga jumlah keseluruhan informasi yang bisa dianalisa lebih jauh ialah sejumlah 51 lembar angket (65\%).

\section{Karakteristik Responden}

\section{Tabel Karakteristik Responden}

\begin{tabular}{|c|c|c|}
\hline \multicolumn{3}{|c|}{ Jenis kelamin respnden } \\
\hline Jenis kelamin & Frequency & Percent \\
\hline Laki-laki & 33 & $65 \%$ \\
\hline Perempuan & 18 & $35 \%$ \\
\hline Total & 51 & $100 \%$ \\
\hline \multicolumn{3}{|c|}{ Jenjang pendidikan respnden } \\
\hline Jenjang Pendidikan & Frequency & Percent \\
\hline D3 & 12 & $24 \%$ \\
\hline S1 & 35 & $68 \%$ \\
\hline $\mathrm{S} 2$ & 4 & $8 \%$ \\
\hline Total & 51 & $100 \%$ \\
\hline \multicolumn{3}{|c|}{ Masa kerja responden } \\
\hline Masa Kerja & Frequency & Percent \\
\hline 1 - 5 Tahun & 5 & $10 \%$ \\
\hline $6-10$ Tahun & 13 & $25 \%$ \\
\hline 11 - 15 Tahun & 22 & $43 \%$ \\
\hline 16-20 Tahun & 11 & $22 \%$ \\
\hline
\end{tabular}


Deni Harianto, dkk: Pengaruh Kejelasan Sasaran Anggaran, Pengendalian Akuntansi.........

\begin{tabular}{|l|c|r|}
\hline Total & 51 & $100 \%$ \\
\hline \multicolumn{2}{|c|}{ Jabatan Pekerjaan Responden } \\
\hline Jabatan & Frequency & Percent \\
\hline Kepala Dinas/Badan & 17 & $33.3 \%$ \\
\hline $\begin{array}{l}\text { Kasubag Perencanaan } \\
\text { Evaluasi dan Pelaporan }\end{array}$ & 17 & $33.3 \%$ \\
\hline Kasubag Keuangan & 17 & $33.3 \%$ \\
\hline Total & 51 & $100 \%$ \\
\hline
\end{tabular}

Responden yang menjadi sampel dalam penelitian ini adalah sebanyak 51 orang. Dilihat dari tabel 4.2 bisa dipahami bahwasanya informan perempuan mendominasi yaitu 33 responden (65\%) dibandingkan dengan responden laki-laki dengan total 18 responden (35\%).

Sesuai jenjang pendidikan, untuk responden jenjang pendidikan Diploma 3 berjumlah 12 orang (24\%), skemudian informan dengan pendidikan Strata 1 adalah sebesar 35 responden (68\%), serta responden dengan jenjang pendidikan Strata 2 adalah sebesar 4 informan (8\%.) Artinya jenjang pendidikan yang mendominasi dimiliki strata 1 sebanyak 35 orang yang berarti tingkat pendidikan Organisasi perangkat daerah Kabupaten Rokan Hilir tersebut lumayan baik.

Responden berdasarkan masa kerja, informan yang mempunyai durasi kerja 1 hingga 5 tahun sebanyak 5 responden (10\%), yang memiliki durasi kerha 6 hingga 10 tahun adalah sebanyak 13 responden (25\%), yang mempunyai durasi kerja kisaran 11 sampai 15 tahun adalah 22 informan (43\%), dan yang bekerja selama >15 tahun adalah 11 orang (22\%) Artinya, informan yang mempunyai pengalaman kerja 11-15 tahun mendominasi di organisasi perangat daerah Kabupaten Rokan Hilir, bisa ditarik konklusi bahwasanya rata-rata pegawai sangat berpengalaman dalam bekerja di organisasi perangat daerah Kabupaten Rokan Hilir.

Berdasarkan jabatannya, informan yang berposisi sebagai Kepala dinas adalah sejumlah 17 responden (33.3\%), 17 responden untuk mereka yang berkedudukan sebagai Sekretaris (33.3\%), dan informan yang berjabatan sebagai Kepala bagian adalah 17 orang (33.3\%).

\section{Hasil Uji Kualitas Data}

Sesudah penghimpunan data, maka terlebih dahulu diperiksa kelengkapannya untuk selanjutnya dianalisa. Kemudian, masuk pada tahap uji validasi dan reliabilitas data. Selanjutnya dilakukan secara keseluruhan jumlah item peryataan yang digunakan untuk mengukur variabel-variabel penelitian. 


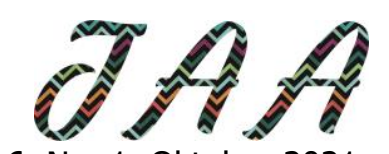

Vol. 6, No. 1, Oktober 2021

Hasil Uji Validitas

\begin{tabular}{|c|c|c|c|c|}
\hline Variabel & Item & $r$ hitung & $r$ tabel & Keterangan \\
\hline \multirow{5}{*}{$\begin{array}{l}\text { KEJELASAN SASARAN } \\
\text { ANGGARAN (X1) }\end{array}$} & $\mathrm{X} 1.1$ & 0.553 & 0.2759 & Valid \\
\hline & $\mathrm{X} 1.2$ & 0.728 & 0.2759 & Valid \\
\hline & $\mathrm{X} 1.3$ & 0.722 & 0.2759 & Valid \\
\hline & $\mathrm{X} 1.4$ & 0.720 & 0.2759 & Valid \\
\hline & $\mathrm{X} 1.5$ & 0.761 & 0.2759 & Valid \\
\hline \multirow{6}{*}{$\begin{array}{l}\text { PENGENDALIAN } \\
\text { AKUNTANSI (X2) }\end{array}$} & $X 2.1$ & 0.609 & 0.2759 & Valid \\
\hline & $X 2.2$ & 0.896 & 0.2759 & Valid \\
\hline & X2.3 & 0.758 & 0.2759 & Valid \\
\hline & X2.4 & 0.780 & 0.2759 & Valid \\
\hline & $\mathrm{X} 2.5$ & 0.839 & 0.2759 & Valid \\
\hline & X2.6 & 0.789 & 0.2759 & Valid \\
\hline \multirow{4}{*}{$\begin{array}{l}\text { SISTEM PELAPORAN } \\
(\mathrm{X} 3)\end{array}$} & X3.1 & 0.799 & 0.2759 & Valid \\
\hline & X3.2 & 0.757 & 0.2759 & Valid \\
\hline & X3.3 & 0.790 & 0.2759 & Valid \\
\hline & X3.4 & 0.773 & 0.2759 & Valid \\
\hline \multirow{7}{*}{$\begin{array}{l}\text { PEMANFAATAN } \\
\text { TEKNOLOGI } \\
\text { INFORMASI (X4) }\end{array}$} & $\mathrm{X} 4.1$ & 0.675 & 0.2759 & Valid \\
\hline & $X 4.2$ & 0.800 & 0.2759 & Valid \\
\hline & $X 4.3$ & 0.676 & 0.2759 & Valid \\
\hline & $X 4.4$ & 0.763 & 0.2759 & Valid \\
\hline & X4.5 & 0.575 & 0.2759 & Valid \\
\hline & $\mathrm{X} 4.6$ & 0.707 & 0.2759 & Valid \\
\hline & $\mathrm{X} 4.7$ & 0.579 & 0.2759 & Valid \\
\hline \multirow{8}{*}{$\operatorname{AKIP}(Y)$} & Y.1 & 0.669 & 0.2759 & Valid \\
\hline & Y.2 & 0.665 & 0.2759 & Valid \\
\hline & Y.3 & 0.586 & 0.2759 & Valid \\
\hline & Y.4 & 0.658 & 0.2759 & Valid \\
\hline & Y.5 & 0.507 & 0.2759 & Valid \\
\hline & Y.6 & 0.658 & 0.2759 & Valid \\
\hline & Y.7 & 0.646 & 0.2759 & Valid \\
\hline & Y.8 & 0.459 & 0.2759 & Valid \\
\hline
\end{tabular}

Sumber : Pengolahan data dengan SPSS, 2020

AKIP diukur menggunakan 8 buah pernyatan semuanya dianggap valid. Kepastian target dana atau anggaran dihitung dengan memakai 5 buah pernyataan semuanya adalah valid. Pengontrolan akuntansi dihitung dengan 6 butir pernyataan yang seluruhnya adalah valid. Sistem pelaporan diukur menggunakan 4 item pernyataan seluruhnya dinyatakan valid. Pendayagunaan teknologi informasi ditakar memakai 7 buah pertanyaan seluruhnya dinyatakan valid. 


\section{Hasil Pengujian Reliabilitas}

Sebuah angket yang reliabel apabila dari jawaban atau pernyataan personalia terhadap pertanyaan ialah konsisten sepanjang waktu. Metode yang dipakai menilai jenjang reabilitas ialah cronbach alpha dengan mengkomparasikan alpha dengan jenjang reabilitas kriterianya. Koefisien cronbach alpha di atas 0,60 mengindikasikan kestabilan (reliabel) instrumen. Tak hanya itu, nilai yang mendekati 1 memperlihatkan makin besar tingkat nalar intern reliabilitas yang dimilikinya.

\section{Tabel 1 Hasil Uji Reliabilitas}

\begin{tabular}{|l|c|c|l|}
\hline \multicolumn{1}{|c|}{ Variabel } & $\begin{array}{c}\text { Cronbach's } \\
\text { Alpha }\end{array}$ & $\begin{array}{c}\text { Standar } \\
\text { Realibilitas }\end{array}$ & Penjelasan \\
\hline $\begin{array}{l}\text { Kejelasan Sasaran Anggaran } \\
(\text { X1) }\end{array}$ & 0.698 & 0.60 & Reliable \\
\hline Pengendalian Akuntansi (X2) & 0.865 & 0.60 & Reliable \\
\hline Sistem Pelaporan (X3) & 0.779 & 0.60 & Reliable \\
\hline $\begin{array}{l}\text { Pemanfaatan Teknologi } \\
\text { Informasi (X4) }\end{array}$ & 0.804 & 0.60 & Reliable \\
\hline $\begin{array}{l}\text { Akuntabilitas Kinerja Instansi } \\
\text { Pemerintah (Y) }\end{array}$ & 0.730 & 0.60 & Reliable \\
\hline
\end{tabular}

Sumber : Pengolahan daeta dengan SPSS, 2020

\section{Statistik Deskriptif}

Data angket yang sudah dihimpun dan dibuatkan tabel sebagai alat analisa data Kemudian hasil dari yang sudah ditabulasikan tadi diolah dengan memakai software SPSS 22 yang memberikan hasil deskripsi statistik variabel studi, sebagaimana yang tampak dalam gambaran berikut ini:

\section{Tabel 2 Statistik Deskriptif}

\section{Descriptive Statistics}

\begin{tabular}{|c|c|c|c|c|c|}
\hline & $\mathrm{N}$ & Minimum & Maximum & Mean & $\begin{array}{c}\text { Std. } \\
\text { Deviation }\end{array}$ \\
\hline KSA & 51 & 15 & 25 & 23.10 & 1.900 \\
PA & 51 & 16 & 29 & 22.39 & 3.262 \\
SP & 51 & 7 & 19 & 14.51 & 2.838 \\
PTI & 51 & 22 & 35 & 28.59 & 2.844
\end{tabular}




\section{JAA}

Vol. 6, No. 1, Oktober 2021

\begin{tabular}{|c|c|c|c|c|c|} 
AKIP & 51 & 29 & 40 & 37.14 & 2.585 \\
Valid N (listwise) & 51 & & & & \\
\hline
\end{tabular}

Sumber: Data Olahan, 2020

Sebagaimana output analisa regresi yang diperlihatkan, maka adapun persamaan regresi yang terformulasikan dalam uji ini ialah:

$\mathrm{Y}=1.331+0,835 \mathrm{X} 1+0,285 \mathrm{X} 2+0,280 \mathrm{X} 3+0,213 \mathrm{X} 4+\mathrm{e}$

\section{Hasil Analisis Regresi Linier Berganda}

Uji hipotesa dengan mengaplikasikan uji regresi linier berganda dalam upaya membuktikan apakah variabel dari kejelasan sasaran anggaran, pengendalian akuntansi, sistem pelaporan, pemanafaatan teknologi terhadap akuntabilits kinerja instansi pemerintah. Pengujian ini dilaksanakan dalam rangka melihat praduga ditolak atau diterima dengan menggunakan multiple regresion (regresi berganda) didalam aplikasi SPSS. Berdasarkan pengujian tersebut diperoleh hasil koefisien regresi yang di lampirkan di bawah ini.

Tabel 3 Analisis Regresi Linier Berganda Hasil Uji Statistik T

Coefficients ${ }^{a}$

\begin{tabular}{|c|c|c|c|c|c|}
\hline \multirow{2}{*}{ Model } & \multicolumn{2}{|c|}{$\begin{array}{c}\text { Unstandardized } \\
\text { Coefficients }\end{array}$} & $\begin{array}{c}\text { Standardized } \\
\text { Coefficients }\end{array}$ & \multirow{2}{*}{$\mathrm{t}$} & \multirow{2}{*}{ Sig. } \\
\cline { 2 - 4 } & $\mathrm{B}$ & Std. Error & Beta & & \\
\hline $\begin{array}{c}\text { (Constant) } \\
\text { Kejelasan }\end{array}$ & 1.331 & 4.497 & & .296 & .769 \\
sasaran anggaran & .835 & .129 & .614 & 6.488 & .000 \\
$\begin{array}{c}\text { Pengendalian } \\
\text { Akuntansi }\end{array}$ & .285 & .081 & .360 & 3.535 & .001 \\
$\begin{array}{c}\text { Sistem pelaporan } \\
\text { Pemanfaatan } \\
\text { teknologi } \\
\text { informasi }\end{array}$ & .280 & .091 & .308 & 3.076 & .004 \\
\hline
\end{tabular}

a. Dependent Variable: Akuntabilitas Kinerja Instansi Pemerintah

\section{Hasil Pengujian Koefisien Determinasi $\left(\mathbf{R}^{\mathbf{2}}\right)$}

Tipe koefisien ini adalah dalam upaya menimbang sejauh mana kapabilitas karakteristik dalam menjelaskan ragam variabel independen. Hasil dari nilai koefisien determinan ialah kisaran 0 dengan 1. 
Deni Harianto, dkk: Pengaruh Kejelasan Sasaran Anggaran, Pengendalian Akuntansi.........

Berikut ini tabel merupakan hasil dari uji koefisien determinasi:

Tabel 4 Hasil Uji Koefisien Determinasi $\left(\mathbf{R}^{2}\right)$

Model Summaryb

\begin{tabular}{|c|c|c|c|c|c|}
\hline Model & $R$ & R Square & $\begin{array}{c}\text { Adjusted R } \\
\text { Square }\end{array}$ & $\begin{array}{c}\text { Std. Error of } \\
\text { the Estimate }\end{array}$ & $\begin{array}{c}\text { Durbin- } \\
\text { Watson }\end{array}$ \\
\hline 1 & $.768^{\mathrm{a}}$ & .590 & .555 & 1.725 & 1.493 \\
\hline
\end{tabular}

a. Predictors: (Constant), Kejelasan Sasaran Anggaran, Pengendalian Akuntansi, Sistem Pelaporan dan Pemanfaatan Teknologi Informasi.

b. Dependent, Sistem pelaporan dan Pemanfaatan Teknologi Informasi

Sumber: Pengolahan data dengan SPSS, 2020

Sebagaimana gambar yang ditampilkan, menunjukkan nilai dari $R$ Square ialah 0,590. Maksudnya, sumbangsih pengaruh variabel bebas terhadap terikat ialah 59,00\%, selebihnya 41,00\% mendapat pengaruh dari variabel lainnya yang di mana tidak dicantumkan pada jenis studi yang dikaji.

\section{Hasil Pengujian Hipotesis dan Pembahasan Tabel 5 Hasil Uji Hipotesis}

\begin{tabular}{|l|l|l|l|l|}
\hline Hipotesis & Thitung & Ttabel & Signifikan & Keterangan \\
\hline $\mathrm{H}_{1}$ & 6.488 & 2.01290 & 0.000 & Berpengaruh \\
\hline $\mathrm{H}_{2}$ & 3.535 & 2.01290 & 0.001 & Berpengaruh \\
\hline $\mathrm{H}_{3}$ & 3.076 & 2.01290 & 0.004 & Berpengaruh \\
\hline $\mathrm{H}_{4}$ & 2.437 & 2.01290 & 0.019 & Berpengaruh \\
\hline
\end{tabular}

\section{Hasil Pengujian Hipotesis $\mathrm{H}_{\mathbf{1}}$}

Dari tabel 9 diatas $\mathrm{H}_{1}$ diterima, maka variabel $\mathrm{X}$ berpengaruh terhadap variabel Y. Pendapat tersebut didukung oleh riset yang dikaji Imam wahid (2016) menyatakan bahwasanya kejelasan sasaran anggaran berdampak pada akuntabilitas kinerja instansi pemerintah.

Terdapatnya sasaran anggaran yang nyata, berarti akan mempermudahkan dalam mengamanahkan kesuksesan/kegagalan penerapan tugas organisasinya memenuhi tujuan serta sasaran yang sudah diputuskan terdahulu.

\section{Hasil Pengujian Hipotesis $\mathrm{H}_{2}$}

Dari tabel diatas $\mathrm{H} 2$ diterima, maka pengendalian akuntansi berpengaruh terhadap akuntabilitas kinerja intansi pemerintah. Perihal tersebut juga di dukung oleh Siti Ruri Suhaesta (2016) yg mengatakan 


\section{$A A$}

Vol. 6, No. 1, Oktober 2021

bahwasanya Pengendalian Akuntansi berpengaruh signifikan pada akuntabilitas kinerja instansi pemerintah.

Pengendalian akuntansi bisa mengukur apakah aktivitas yang dikerjakan pemerintah itu sudah serta irit, optimal serta daya guna servis lembaga pemerintahan daerah ke orang-orang, ialah parameter unjuk kerja pemerintah daerah.

\section{Hasil Pengujian Hipotesis $\mathbf{H}_{3}$}

Dari tabel diatas $\mathrm{H}_{3}$ diterima, maka sistem pelaporan berpengaruh terhadap akuntabilitas kinerja instansi pemerintah. Berdasarkan penelitian yang dilakukan oleh Reyhan Handy Fauzan (2017) menyatakan bahwasanya ada korelasi positif terhadap sistem pelaporan terhadap akuntabilitas lembaga pemerintah. Siti Ruri Suhaesta (2016) juga mengungkapkan bahwasanya mekanisme pertanggungjawaban berdampak pada responsibilitas kompetensi lembaga kepemerintahan. Sedangkan menurut Eko Setiawan (2013) tidak ada pengaruh antara prosedural pertanggungjawaban pada akuntabilitas kinerja lembaga pemerintah.

Sistem pelaporan ialah pertanggungjawaban mencerminkan struktur responsibilitas dari anggota ke pimpinan. Mekanisme yang bagus dibutuhkan supaya bisa mengawasi serta mengontrol kinerja manejerial didalam menjalankan anggaran yang sudah diputuskan (Abdullah,2005).

\section{Hasil Pengujian Hipotesis $\mathbf{H}_{4}$}

Dari tabel diatas $\mathrm{H}_{4}$ diterima, maka pemanfaatan teknologi informasi berpengaruh terhadap akuntabilitas kinerja instansi pemerintah. Sementara Razi (2017) mengatakan bahwa informasi teknologi mempunyai peranan penting dalam pengembangan pelayanan bagian publik. Chintya (2015) mengklaim bahwa pemanfaatan teknologi informasi berdampak pada kinerja instansi pemerintah pada penilitian yang dilaksanakan di kota solok.

Razi (2017) menerangkan, pemanfaatan teknologi informasi ialah "manfaat yang diinginkan oleh pemakai sistem informasi didalam mengerjakan tugasnya ataupun pekerjaan". Satu di antara kegunaan yang sangat dikehendaki misalnya pengembangkan abilitas yang menjadi ranah dari Akuntabilitas Kinerja Instansi.

\section{Kesimpulan, Keterbatasan Penelitian dan Saran}

Sebagaimana hasil penelitian dan pembahasan yang telah dilakukan dapat disimpulkan bahwa :Kjelasan Sasaran Anggaran, Pengontrolan Akuntansi, Mekanisme Pertanggungjawaban serta Pendayagumaan Teknologi Informasi berpengaruh kepada Responsibilitas Kinerja Lembaga Pemerintah.

Riset yang dilakukan mempunyai sejumlah keukurangan, misalnya: 1) Peneliti tak bisa secara langsung memberikan angket kepada informan 
serta menemaninya menjejali angkey 2) Pada fase penghimpunan informasi, data yang peneliti peroleh dari angket yang diisi acapkali merujuk pada opini informan yang sebetulnya.

Saran pada riset yang dikaji ialah: 1) Peneliti selanjutnya perlu memperluas ruang lingkup penelitian sehingga hasil penelitian selanjutnya diharapkan dapat diterapkan dan berlaku secara umum. 2) Penelitian selanjutnya sebaiknya memperpanjang jangka area penelitian. 3) penelitian selanjutnya diharpakan peneliti mendampingi langsung para responden dalam mengisi kuesioner yag diberikan sehingga responden paham dalam mengisi kuesioner tersebut.

\section{DAFTAR PUSTAKA}

Abdullah, Hilmi. 2005. Pengaruh Kejelasan Sasaran Anggaran, Pengendalian Akuntansi, dan Sistem Pelaporan Terhadap KInerja Instansi Pemerintah pada Kabupaten dan Kota di Daerah Istimewa Yogyakarta. Tesis. Yogyakarta : Universitas Gajah Mada.

Abdul, Halim. 2002. Akuntansi Sektor Publik Akuntansi Keuangan Daerah. Edisi pertama, Salemba Empata, Jakarta.

Agus Saputra. 2012. Membuat Aplikasi Absensi Dan Kuesioner untuk Panduan Skripsi. PT. Elex Media Komputindo. Jakarta.

Anjarwwati, Mei. 2021. Pengaruh Kejelasan Sasaran Anggaran, Pengendalian Akuntansi dan Sistem Pelaporan terhadap Akuntabilitas Kinerja Instansi Pemerintah (Studi pada SKPD seKabupaten, Kota Tegal dan Kabupaten Pemalang).Under Graduatesthesis.Semarang: Universitas Negeri Semarang

Badan Pengawasan Keuanhan dan Pembangunan. 2011. Akuntabilitas Instansi Pemerintah. Jakarta

Carter, K. William. 2009. Akuntansi Biaya, perencanaan dan pengendalian biaya. Edisi 14, Salemba Empat, Jakarta.

Cefrida, Mentari. 2014. Pengaruh Kejelasan Sasaran Anggaran, Pengendalian Akuntansi Sektor Publik dan Ketaatan Pada Peraturan Perundang-undangan Terhadap Akuntabilitas Kinerja Instansi Pemerintah Kota Pekanbaru. Jurnal. Pekanbaru : Universitas Riau.

Darma, R. 2004. "Pengaruh Kejelasan Sasaran dan Sistem Pengendalian Akuntansi Terhadap Kinerja Manajerial dengan Komitmen Organisasi sebagai Variabel Pemoderasi pada Pemerintah Daerah". Tesis. Yogyakarta : Program Pasca Sarjana UGM.

Darwanis dan Sephi Chairunnisa. 2013. "Akuntabilitas Kinerja Instansi Pemerintah". Universitas Syiah Kuala. Jurnal Telaah \& Riset Akuntansi. Vol. 6, No. 2.

Ghozali, Imam. 2008. Aplikasi Analisis Multivariance dengan program SPSS. Semarang. Badan Penerbit : Universitas Diponegoro. 


\section{JAA}

Vol. 6, No. 1, Oktober 2021

Halim. 2004. Reformasi Akuntansi Keuangan dan Anggaran Daerah. Dua Pilar Utama Manajemen Keuangan Daerah. Yogyakarta : Pidato Penyuluhan Jabatan Guru Besar pada Fakultas Ekonomi Universitas Gajahmada.

Halim, Abdul, 2004.Akuntansi Keuangan Daerah, Penerbit Salemba Empat, Jakarta.

Herawaty, Netty. 2011. Pengaruh Kejelasan Sasaran Anggaran, Pengendalian Akuntansi, dan Sistem Pelaporan Terhadap Akuntabilitas Kinerja Instansi Pemerintah Daerah Kota Jambi. Jurnal Penelitian Universitas Jambi Seri Humaniora. Volume 13, Nomor 2, Hal 31-36, ISSN 0852-8349. Jurnal Jambi. Universitas Jambi.

Inpres Nomor 7 Tahun 1999 Tentang Akuntabilitas Kinerja Instansi Pemerintah.

Irawan. Dedi, Juni 2018. Pengaruh Pemanfaatan Teknologi Informasi, Kualitas Sumber Daya Manusia, Pengendalian Intern dan Komitmen Organisasi Terhadap Keterandalan Pelaporan Keuangan Pemerintah Daerah (Studi Empiris Pada Organisasi Perangkat Daerah Kabupaten Rokan Hilir).

Kusumaningrum, Indraswari. 2010. Pengaruh Kejelasan Sasaran Anggaran, Sistem Pelaporan dan Pengendalian Akuntansi terhadap Akuntabilitas Kinerja Instansi Pemerintah Provinsi Jawa Tengah. Tesis.Universitas Diponegoro: Program Pascasarjana

Lembaga Administrasi Negara Republik Indonesia (2003), Keputusan Kepala Lembaga Administrasi Negara No. 239/IX/6/8/2003 tentang Perbaikan Pedoman Penyusunan Pelaporan Akuntabilitas Kinerja Instansi Pemerintah.

Mardiasmo.2009. Akuntabilitas Sektor Publik. Penerbit Andi. Yogyakarta.Mardiasmo. 2002. Akuntansi Sektor Publik. Penerbit Andi. Yogyakarta.

Mayangsari S. Dan Puspa Wandanarum,2009, "Pendekatan Sektor Publik dan Privat". Buku 1, Jakarta: Media Bangsa.

Suhartono, Ehrmann; Solichin, Mochammad, 2007. Pengaruh Kejelasan

Sasaran Anggaran terhadap Senjangan Anggaran Instansi Pemerintah Daerah dengan Komitmen Organisasi sebagai Pemoderasi. Jurnal Akuntansi dan Keuangan Sektor Publik, Vol. 08 No. 01, Jogjakarta.

Sugiyono. 2013. Metode Penelitian Pendidikan Pendekatan Kuantitatif, Kualitatif, dan $R \& D$. Bandung : Alfabeta.

Suprapto, J. 2002. Pengukuran Tingkat Kepuasan Pelanggan Untuk Menaikkan Pangsa Pasar. Jakarta : Rineka Cipta

Undang-Undang RI Nomor 1 tahun 2004 tentang Perbendaharaan Negara. 
Wahyuni. 2014. Pengaruh Kejelasan Sasaran Anggaran, Pengendalian Akuntansi, dam Sistem Pertanggungjawabam terhadap Akuntabilitas Kinerja Instansi Pemerintah (Studi pada Satuan Kerja Perangkat Desa Kabupaten Rokan Hulu). Jurnal Pekanbaru: Universitas Riau.

Zakiyudin, Ali dan Suyanto. 2015. "Kejelasan Sasaran Anggaran, Pengendalian Akuntansi, Sistem Pelaporan dan Akuntabilitas Kinerja Instansi Pemerintah". Jurmal Riset Akuntansi dan Perpajakan Vol. 2 Nomor 1 hal. 89-96. 